\title{
ANALISIS BEBAN KERJA TENAGA REKAM MEDIS RUMAH SAKIT BEDAH SURABAYA MENGGUNAKAN METODE FTE
}

\author{
Workload Analysis of Rumah Sakit Bedah Surabaya's Medical Record Staff using FTE Methods
}

\author{
Dwi Trisana Wardanis
}

Politeknik Kesehatan Kemenkes Surabaya, Indonesia

E-mail: dwiwardanis@yahoo.com

\begin{abstract}
Workload analysis is a human resource planning activity to determine of staff needs so organization goals can be achieved. Human resources planning at Rumah Sakit Bedah Surabaya is done periodically using Workload Indicator Staff Need (WISN), this method is subjective. Based on the calculation using the WISN method, there is a discrepancy between the number of existing and the required staff, including in the Medical Record Unit of Rumah Sakit Bedah Surabaya. There is an excess of medical record staff that will impact on employee productivity. Therefore, so important to measure objective workload based on real condition in the field. There are several methods that can be used to analyze the objective workload, one of them is Full Time Equivalent (FTE). Data on the workload is obtained by interview and daily log which will be analyzed and converted into FTE index. Based on the results of the analysis it is found that the workload of supervisor and medical recorder of morning shift is normal, but for the shift of the afternoon, night and helper are underload. The medical record staff owned by Rumah Sakit Bedah Surabaya has been sufficient to handle the patient's medical record needs
\end{abstract}

Keywords: full time equivalent, medical record, workload analysis

\section{ABSTRAK}

Analisis beban kerja merupakan kegiatan perencanaan sumber daya manusia yang bertujuan untuk mengetahui kebutuhan tenaga sehingga tujuan organisasi dapat tercapai. Perencanaan sumber daya manusia di Rumah Sakit Bedah Surabaya meliputi perhitungan kebutuhan jumlah karyawan dilakukan secara berkala menggunakan metode Workload Indicator Staff Need (WISN) yang bersifat subjektif. Berdasarkan hasil perhitungan menggunakan metode WISN, terjadi ketidaksesuaian antara jumlah tenaga yang ada dengan tenaga yang dibutuhkan, termasuk di unit Rekam Medis Rumah Sakit Bedah Surabaya. Terdapat kelebihan jumlah tenaga rekam medis dibandingkan dengan yang dibutuhkan, hal ini akan berdampak pada produktivitas karyawan. Oleh karena itu diperlukan adanya pengukuran beban kerja objektif berdasarkan kondisi nyata yang ada di lapangan. Terdapat beberapa metode yang dapat digunakan untuk menganalisis beban kerja objektif, salah satunya adalah Full Time Equivalent (FTE). Data mengenai beban kerja didapatkan melalui pencatatan pada instrumen berupa daily log dan wawancara, selanjutnya dianalisis dan dikonversikan ke dalam nilai indeks FTE. Berdasarkan hasil analisis didapatkan bahwa beban kerja supervisor dan pelaksana rekam medis shift pagi tergolong normal, namun untuk pelaksana shift sore, malam dan helper memiliki beban kerja yang tergolong rendah (underload). Tenaga rekam medis yang dimiliki oleh Rumah Sakit Bedah Surabaya telah mencukupi untuk menangani kebutuhan berkas rekam medis pasien

Kata kunci: analisis beban kerja, full time equivalent, rekam medis

\section{PENDAHULUAN}

Sumber daya manusia (SDM) merupakan salah satu komponen penting dalam organisasi sehingga keberadaannya perlu dikelola dengan baik. Fungsi manajemen sumber daya manusia (MSDM) menurut Griffith \& White (2010) antara lain perencanaan, pengembangan, pemeliharaan dan pemberdayaan tenaga kerja, kompensasi serta penilaian kinerja organisasi. Menurut Marlina (2015) proses perencanaan SDM merupakan cara atau kegiatan yang dilakukan untuk menetapkan tujuan dan pedoman pelaksanaan serta menjadi dasar kontrol atau pengendalian pegawai. Tujuan perencanaan SDM meliputi menentukan kualitas dan kuantitas pegawai yang akan mengisi jabatan dalam organisasi, menjamin ketersediaan tenaga kerja masa kini maupun masa depan, menghindari adanya tumpang tindih dalam pelaksanaan tugas, menghindari adanya kelebihan pegawai meningkatkan produktivitas dan menjadi pedoman dalam menetapkan program seleksi, pengembangan, pemeliharaan, kompensasi, pengintegrasian dan pemberhentian pegawai.

Ketersediaan SDM yang dibutuhkan untuk pelaksanaan tugas pada masa yang akan datang sangat penting untuk memastikan bahwa kegiatan 
perusahaan dapat terlaksana dengan baik. Tindakan yang akan dilakukan harus direncanakan sebelumnya untuk memastikan atau meminimalkan gangguan pada rencana perusahaan. Jumlah pegawai yang lebih besar daripada kebutuhan mengimplikasikan bahwa perusahaan kurang baik dalam mengelola sumber daya manusia demikian juga sebaliknya. Fokus perhatian perencanaan SDM ditujukan pada proses peramalan dan penentuan kebutuhan SDM di masa depan (Hariandja, 2002).

Ketepatan jumlah karyawan yang dipekerjakan dalam suatu sistem produksi, merupakan kondisi dasar yang harus diperhatikan dalam menyusun perancangan kerja. Proses perancangan kerja pada akhirnya bertujuan untuk menyeimbangkan aspek fisik dan mental manusia dalam menyelesaikan tugas tertentu sehingga ketepatan jumlah karyawan dengan beban kerja yang ada akan mendukung kondisi mental maupun fisik saat bekerja (Dannies, et al., 2015).

Perencanaan SDM merupakan salah satu tugas yang harus dilakukan Unit Manajemen Sumber Daya Manusia (MSDM) di Rumah Sakit Bedah Surabaya. Perencanaan SDM yang dilakukan bertujuan untuk mengetahui kebutuhan SDM tiap unit dan proses rekrutmen karyawan di periode yang akan datang. Unit MSDM Rumah Sakit Bedah Surabaya menggunakan metode WISN (Workload Indicator Staff Need) mengacu kepada KEPMENKES RI Nomor 81/Menkes/SK/I/2004 untuk menentukan kebutuhan tenaga di periode selanjutnya. WISN merupakan suatu metode perhitungan kebutuhan SDM kesehatan berdasarkan pada beban pekerjaan nyata yang dilaksanakan oleh tiap kategori SDM kesehatan pada tiap unit kerja di fasilitas pelayanan kesehatan.

Perhitungan kebutuhan SDM di Rumah Sakit Bedah Surabaya pada awalnya dilakukan secara berkala oleh supervisor tiap unit yang telah mengetahui dengan baik kegiatan yang dilakukan dan jumlah tenaga yang diperlukan. Kegiatan ini telah tercantum dalam uraian tugas supervisor. Namun, selama pelaksanaannya kerap terjadi bias dikarenakan penilaian yang bersifat subjektif. Oleh karena itu, saat ini perhitungan pola ketenagaan Rumah Sakit Bedah Surabaya dilakukan oleh unit MSDM dengan tetap melakukan konfirmasi dan klarifikasi mengenai uraian pekerjaan dan frekuensi pekerjaan kepada karyawan dan supervisor unit terkait. Data yang dibutuhkan antara lain uraian kegiatan pokok yang dilakukan dan alokasi waktu yang dibutuhkan. Selanjutnya berdasarkan data tersebut dilakukan perhitungan kebutuhan SDM pada periode tertentu berdasarkan standar beban kerja karyawan.

Perhitungan menggunakan metode WISN yang selama ini dilakukan bersifat subjektif dikarenakan pengumpulan data yang dilakukan melalui wawancara tidak dilakukan kepada semua tenaga kerja yang ada di unit tersebut dan juga lama waktu pelaksanaan kegiatan ditetapkan berdasarkan persepsi karyawan yang bertindak sebagai responden. Oleh karena itu, diperlukan adanya pengukuran yang lebih objektif. Setiawan \& Wulandari (2016) menyebutkan bahwa beban kerja objektif merupakan perhitungan beban kerja berdasarkan keadaan nyata yang ada di lapangan. Pengukuran beban kerja objektif ini berguna mengetahui kebutuhan tenaga yang sebenarnya.

Full Time Equivalent (FTE) merupakan salah satu metode analisis beban kerja yang dilakukan dengan membandingkan waktu penyelesaian pekerjaan dan waktu kerja yang tersedia secara subjektif. Pengukuran nilai FTE dilakukan dengan menghitung beban kerja semua pegawai dalam satu unit kerja pada periode tertentu. Metode FTE mengukur beban kerja suatu organisasi selama satu tahun dan untuk mengukur semua aktivitas pekerjaan berdasarkan deskripsi pekerjaan yang ada. Nilai yang didapatkan menunjukkan beban kerja dan juga jumlah tenaga yang dibutuhkan untuk menyelesaikan pekerjaan (Supriyatna, 2013).

Metode WISN yang diterapkan di Rumah Sakit Bedah Surabaya digunakan untuk menghitung pola kebutuhan di semua unit, baik unit pelayanan ataupun non pelayanan. Pelaksanaan perhitungan pola ketenagaan dilakukan setiap tahun untuk menjadi pedoman dalam melakukan perencanaan kebutuhan SDM rumah sakit di tahun yang akan datang. Berdasarkan perhitungan pola ketenagaan menggunakan metode WISN sering terdapat ketidaksesuaian antara jumlah tenaga yang dibutuhkan dengan jumlah tenaga yang telah ada. Salah satu unit yang memiliki perbedaan antara jumlah tenaga yang tersedia dengan hasi perhitungan kebutuhan adalah Unit Rekam Medis. Berdasarkan hasil perhitungan menggunakan metode WISN didapatkan bahwa kebutuhan tenaga di unit Rekam Medis Rumah Sakit Bedah Surabaya adalah sebanyak 5 orang. Realisasi alokasi tenaga yang ada saat ini berjumlah 5 orang tenaga rekam medis dan dibantu dengan 1 orang helper. Sehingga dapat dikatakan bahwa tenaga yang ada di unit Rekam Medis berjumlah 6 orang dimana terdapat kelebihan jumlah tenaga. Oleh karena itu, penelitian ini dilakukan untuk menghitung beban kerja objektif tenaga rekam medis dan menentukan jumlah optima SDM yang dibutuhkan di unit Rekam Medis dalam memenuhi pelayanan berkas rekam medis Rumah Sakit Bedah Surabaya mengunakan metode Full Time Equivalent (FTE).

\section{METODE}

Jenis penelitian ini merupakan penelitian observasional dengan pendekatan deskriptif analitik. Populasi dalam penelitian ini yaitu seluruh tenaga yang ada di unit Rekam Medis Rumah Sakit Bedah Surabaya dengan sampel penelitian menggunakan total dari populasi yaitu 5 orang tenaga rekam medis dan 1 orang helper. Data beban kerja diperoleh dari daily log dan wawancara.

Setiawan \& Wulandari (2016) menyebutkan bahwa pengumpulan data dalam perhitungan beban kerja personal dapat dilakukan dengan daily log. Daily log cukup sesuai untuk digunakan dalam mengetahui beban kerja rekam medis karena pekerjaan rekam medis yang berhubungan dengan kegiatan administratif memungkinkan untuk menuliskan 
sendiri kegiatan dan waktu yang digunakan untuk melakukan pekerjaan. Lembar daily log berisi komponen uraian kegiatan, deskripsi kegiatan, alokasi waktu pelaksanaan kegiatan, volume pekerjaan dan frekuensi pelaksanaan kegiatan. Sebelum dilakukan penelitian, diberikan penjelasan terlebih dahulu mengenai cara pengisian tiap komponen pada lembar daily log. Pengisian dilakukan selama 3 hari kerja untuk supervisor dan 4 hari kerja untuk pelaksana rekam medis dan helper.

Selanjutnya dilakukan wawancara untuk memastikan kembali uraian kegiatan yang telah dicatat pada lembar daily log. Proses ini mencegah terjadinya kesalahan perhitungan dikarenakan adanya uraian kegiatan yang belum tercatat. Pengumpulan data dilakukan dari hari Kamis tanggal 28 September hingga Senin tanggal 02 Oktober 2017. Dikarenakan tiap pelaksana rekam medis setiap harinya memiliki shift kerja yang berbeda-beda, maka penulis mengelompokkan beban kerja tahunan dan juga nilai indeks FTE pelaksana rekam medis ke dalam 3 kategori yaitu pelaksana rekam medis shift pagi, sore dan malam.

Langkah pertama dalam melakukan analisis beban kerja menggunakan metode FTE yaitu membuat tabel aktivitas dan waktu kerja. Tabel aktivitas kerja berisi deskripsi pekerjaan dan waktu yang dibutuhkan untuk menyelesaikan aktivitas tersebut selama 1 siklus/periode kerja. Langkah kedua yaitu menghitung total waktu kerja tersedia tiap kategori SDM yang ada di Unit Rekam Medis. Langkah ketiga adalah menghitung beban kerja tahunan berdasarkan data uraian pekerjaan dan alokasi waktu yang tercatat pada daily log dengan menjumlahkan seluruh waktu kerja yang dibutuhkan selama periode tertentu. Langkah selanjutnya yaitu menghitung waktu kelonggaran. Waktu kelonggaran adalah waktu kerja yang digunakan untuk keperluan pribadi, seperti pergi ke toilet, beribadah, makan siang dan istirahat. Langkah terakhir yaitu menghitung Nilai Indeks FTE berdasarkan rumus.

$$
\text { Indeks FTE }=\frac{\text { Total Waktu kerja riil /tahun }}{\text { Waktu kelonggarantahun }}
$$

Total waktu kerja riil per tahun didapatkan dari perhitungan beban kerja tahunan. Total waktu kerja tersedia didapatkan dari jumlah hari kerja tersedia tiap kategori SDM dikalikan dengan jam kerja tiap kategori SDM. Jika didapatkan perhitungan indeks nilai FTE yang berada antara 1,00-1,28 memiliki arti bahwa beban kerja masih dalam batas normal. Indeks nilai FTE $>1,28$ memiliki arti bahwa beban kerja diatas normal atau overload dan jika indeks nilai FTE $<1,00$ memiliki arti bahwa beban kerja dibawah batas normal atau underload. Indeks nilai FTE dapat dikonversikan menjadi standar jumlah tenaga kerja yang dibutuhkan, yaitu bila indeks nilai FTE $>1,28$ maka jumlah orang yang dibutuhkan adalah 2 orang. Indeks nilai FTE $>2,56$ membutuhkan 3 orang tenaga kerja dan seterusnya (Sugiono \& Palit, 2016).

\section{HASIL DAN PEMBAHASAN}

Rekam medis menurut Permenkes RI Nomor 55 Tahun 2013 adalah berkas yang berisikan catatan dan dokumen tentang identitas pasien, pemeriksaan, pengobatan, tindakan dan pelayanan lain yang telah diberikan kepada pasien pada suatu pelayanan kesehatan. Berkas rekam medis di suatu pelayanan kesehatan dikelola oleh tenaga rekam medis atau perekam medis yang berdasarkan kompetensi dan pendidikannya bertugas untuk memberikan pelayanan rekam medis dan informasi kesehatan pasien.

Tenaga rekam medis di Rumah Sakit Bedah Surabaya bertanggungjawab dalam proses perakitan, kelengkapan berkas rekam medis, pengembalian dan peminjaman berkas, penyimpanan, kerahasiaan dan keamanan berkas dan juga keakuratan data yang digunakan sebagai laporan pihak rumah sakit. Semakin bertambahnya jumlah pasien, semakin tinggi pula pelayanan rekam medis yang dibutuhkan.

Peningkatan kebutuhan pelayanan berkas rekam medis dapat meningkatkan beban kerja yang dialami oleh tenaga rekam medis. Oleh karena itu, diperlukan adanya suatu perhitungan beban kerja objektif sehingga dapat diketahui jumlah tenaga yang dibutuhkan. Pengukuran beban kerja dapat dilakukan secara subjektif dan juga objektif. Beban kerja subjektif adalah ukuran yang umumnya digunakan dalam menjawab tentang persepsi terhadap beban kerja, tekanan dan kepuasan kerja yang dilihat berdasarkan beban kerja fisik, mental dan sosial. Sedangkan beban kerja objektif merupakan beban kerja yang diukur secara nyata sesuai dengan keadaan di lapangan. Beban kerja objektif diukur berdasarkan keseluruhan waktu yang digunakan untuk melakukan aktivitas atau pekerjaan (Setiawan \& Wulandari, 2016).

Perhitungan kebutuhan tenaga medis dan non medis berdasarkan beban kerja dilakukan oleh Rumah Sakit Bedah Surabaya menggunakan metode WISN. Penelitian yang dilakukan oleh Permatasari \& Pudjirahardjo (2015) menyebutkan bahwa perhitungan beban kerja menggunakan metode WISN umumnya menggunakan data sekunder yang mungkin belum dijamin kelengkapannya sehingga dapat menimbulkan kurangnya data yang dianalisis dan memberikan hasil yang kurang akurat. Kelemahan utama melakukan perhitungan beban kerja dengan metode WISN adalah sangat tergantung pada kelengkapan dan keakuratan data. Adanya uraian tugas ataupun kegiatan riil yang tidak tercatat dan tidak masuk ke perhitungan dapat memberikan hasil kebutuhan tenaga kerja yang lebih sedikit. Selain itu, penerapan metode WISN tidak memperhatikan produktivitas kerja dari tenaga yang ada sehingga pekerjaan yang terhitung belum tentu sampai pada menghasilkan pelayanan yang optimal. Perlu dilakukan perhitungan beban kerja obyektif untuk melihat kesesuaian beban kerja yang terjadi di lapangan.

Adanya ketidaksesuaian antara hasil perhitungan kebutuhan tenaga di unit Rekam Medis 
berdasarkan metode WISN dengan jumlah tenaga yang ada di lapangan menuntut adanya perhitungan menggunakan metode lain sebagai perbandingan. FTE merupakan metode yang umumnya digunakan untuk mengatur efektivitas dan efisiensi tenaga kerja berdasarkan waktu kerja yang dibutuhkan. FTE dapat diterapkan untuk menghitung beban kerja karyawan di semua sektor, termasuk sektor kesehatan. Metode FTE telah banyak diaplikasikan untuk menghitung kebutuhan tenaga medis seperti dokter ataupun tenaga kesehatan lain seperti perawat, bidan dan juga petugas rekam medis.

FTE dilakukan dengan menganalisis, mengambil keputusan dan mengimplementasikan proses yang menentukan jumlah pegawai yang dibutuhkan. Beberapa hal penting yang perlu diperhatikan dalam melakukan perhitungan beban kerja dan kebutuhan tenaga menggunakan metode FTE yaitu spesifikasi proses kinerja, standar beban kerja untuk suatu proses atau aktivitas dan jumlah jam kerja pada suatu posisi pekerjaan (Susilo \& Yustiawan, 2015).

Implikasi dari nilai FTE terbagi menjadi 3 jenis yaitu overload, normal dan underload. Beban kerja yang terlalu berat atau terlalu ringan akan mengakibatkan terjadi inefisiensi kerja. Beban kerja berlebih (overload) mengindikasikan bahwa jumlah tenaga yang dipekerjakan tidak sesuai dengan beban kerja yang diterima sehingga dapat memicu terjadinya kelelahan fisik dan juga psikologis yang nantinya akan berdampak pada produktivitas tenaga kerja. Beban kerja yang terlalu rendah (underload) mengindikasikan bahwa jumlah tenaga yang dialokasikan terlalu banyak sehingga perusahaan harus mengalokasikan biaya untuk gaji karyawan lebih banyak yang menyebabkan terjadinya inefisiensi biaya (Tridoyo \& Sriyanto, 2014).

Pelaksanaan perhitungan beban kerja obyektif tenaga unit Rekam Medis menggunakan metode FTE dilakukan dengan menghitung beban kerja riil berdasarkan waktu yang dibutuhkan tenaga rekam medis dalam melakukan tugas dan tanggung jawabnya. Proses pelaksanaan analisis beban kerja tenaga rekam medis yang ada di Rumah Sakit Bedah Surabaya menggunakan metode FTE dimulai dengan membuat instrumen berupa daily log. Daily log atau pencatatan kegiatan sendiri merupakan bentuk sederhana dari work sampling, yaitu pencatatan yang dilakukan sendiri oleh SDM yang diamati (Setiawan \& Wulandari, 2016)

Instrumen daily log berisikan tabel aktivitas, waktu kerja, frekuensi kegiatan dan volume pekerjaan yang dilakukan karyawan. Kolom volume pekerjaan bertujuan untuk mempermudah dalam menganalisis kesesuaian beban kerja dengan output kerja yang dihasilkan. Sebelum dilakukan pengisian pada daily log diberikan penjelasan mengenai tiap komponen yang ada dalam tabel beserta cara pengisian kepada seluruh tenaga rekam medis untuk menghindari adanya kesalahan dalam melakukan pengisian.

Setelah dilakukan pengisian pada instrumen penelitian, langkah selanjutnya adalah melakukan perhitungan waktu tersedia seluruh kategori SDM di unit Rekam Medis Rumah Sakit Bedah Surabaya. Waktu kerja tersedia dalam satu tahun diperoleh dari banyaknya hari kerja tersedia dalam satu tahun dikalikan dengan jam kerja karyawan. Dalam unit Rekam Medis terdapat 3 kategori SDM yang berbeda yaitu supervisor, pelaksana rekam medis dan helper. Supervisor bekerja selama 5 hari dalam satu minggu dan memiliki waktu kerja 8,6 jam per hari. Pelaksana rekam medis dan helper memiliki 6 hari kerja dan waktu kerja pelaksana rekam medis per hari selama 7 jam sedangkan helper selama 8 jam per hari. Adapun perhitungan waktu kerja tersedia untuk ketiga kategori tersebut adalah sebagai berikut:

Hari kerja tersedia yang dimiliki oleh supervisor adalah 231 hari per tahun dan memiliki jam kerja 8.6 jam per hari, dan didapatkan bahwa waktu kerja tersedia bagi supervisor rekam medis adalah 1.987 jam per tahun. Hari kerja tersedia untuk pelaksana rekam medis adalah 288 hari per tahun dengan jam kerja sebanyak 7 jam per hari sehingga didapatkan bahwa waktu kerja tersedia untuk pelaksana rekam medis adalah 2.016 jam per tahun. Hari kerja tersedia untuk helper adalah 288 hari per tahun dengan waktu kerja selama 8 jam per hari sehingga didapatkan waktu kerja tersedia bagi helper adalah 2.304 jam per tahun.

Setelah mengetahui waktu kerja tersedia yang dimiliki masing-masing kategori SDM di unit Rekam Medis Rumah Sakit Bedah Surabaya maka langkah selanjutnya adalah melakukan perhitungan beban kerja tahunan. Data beban kerja diperoleh dari hasil pengisian lembar daily log. Total waktu yang diperlukan tenaga rekam medis dalam melakukan pekerjaan, selanjutnya dikonversikan ke dalam satuan tahun. Konversi dilakukan dengan menggunakan analisis trend linier. Analisis trend dilakukan untuk menentukan prediksi volume pekerjaan yang dilakukan berdasarkan banyaknya volume pekerjaan di periode sebelumnya.

Berdasarkan pencatatan pada daily log, waktu yang diperlukan untuk melakukan pekerjaan rekam medis shift pagi membutuhkan waktu selama 4-6 jam per hari, sedangkan untuk shift sore membutuhkan waktu kerja selama 3-5 jam per hari dan shift malam membutuhkan waktu kerja selama 1-2 jam per hari. Supervisor rekam medis membutuhkan waktu kerja selama 5-6 jam dalam satu hari dan helper membutuhkan waktu kerja selama 4 jam dalam satu hari. Untuk mengetahui total waktu kerja selama satu tahun dilakukan analisis trend dan dikonversikan dalam satuan tahun. Adapun hasil beban kerja tahunan tenaga rekam medis di unit Rekam Medis adalah sebagai berikut:

Tabel 1. Hasil Perhitungan Beban Kerja Tahunan Tenaga unit Rekam Medis

\begin{tabular}{lcc}
\hline \multicolumn{1}{c}{ Jabatan } & $\begin{array}{c}\text { Total waktu } \\
\text { kerja tersedia } \\
\text { (jam/ tahun) }\end{array}$ & $\begin{array}{c}\text { Total waktu } \\
\text { kerja riil } \\
\text { (jam/ tahun) }\end{array}$ \\
\hline Supervisor & 1.987 & 2.184 \\
Pelaksana Pagi & 2.016 & 2.132 \\
Pelaksana Sore & 2.016 & 1.500 \\
Pelaksana Malam & 2.016 & 546 \\
Helper & 2.304 & 1.403 \\
\hline
\end{tabular}


Hasil perhitungan menunjukkan bahwa waktu kerja terbanyak dimiliki oleh supervisor dan pelaksana rekam medis shift pagi. Hal ini dikarenakan pada saat jam kerja shift pagi, pasien yang melakukan pemeriksaan baik rawat jalan, IGD dan rawat inap relatif lebih banyak dari waktu kerja lainnya. Uraian kegiatan yang dilakukan pelaksana rekam medis antara lain coding, assembling, filing, peminjaman berkas, permintaan data serta distribusi berkas.

Berdasarkan perhitungan didapatkan pula waktu kerja yang dilakukan supervisor melebihi waktu kerja tersedia yang dimiliki dikarenakan uraian tugas dan tanggung jawab yang dimiliki supervisor lebih banyak. Waktu kerja supervisor dialokasikan untuk melakukan tugas rekam medis seperti entry data, coding, permintaan data, merekap data dan juga kegiatan lainnya seperti weekly report, membuat laporan bulanan dan briefing.

Total waktu kerja yang digunakan pelaksana rekam medis shift sore lebih sedikit dari total waktu kerja yang tersedia. Jam kerja produktif yang digunakan saat melakukan pekerjaan sore hari sebesar $74 \%$ dari jam kerja yang ditetapkan. Kegiatan yang dilakukan di shift sore tidak jauh berbeda oleh shift pagi namun karena jumlah pasien pada saat shift sore lebih sedikit sehingga waktu kerja yang dibutuhkan juga menjadi sedikit. Berdasarkan uraian kegiatan yang tercatat pada daily log, terdapat beberapa kegiatan yang membutuhkan alokasi waktu cukup lama saat melakukan pekerjaan pada shift sore antara lain pengisian berkas asuransi pasien poli rawat jalan, memastikan kelengkapan berkas rekam medis, peminjaman berkas dan distribusi berkas rekam medis.

Total waktu kerja terendah dialami oleh pelaksana shift malam. Produktivitas dalam melakukan kegiatan saat shift malam menurun hingga $20 \%$, hal ini dikarenakan saat shift malam hanya melayani berkas untuk pasien IGD. Selain itu, waktu kerja shift malam digunakan untuk distribusi berkas rekam medis pasien IGD dan juga telusur berkas rekam medis yang belum kembali baik dari poli, IGD ataupun dari peminjaman rekam medis. Waktu lain yang tersisa digunakan untuk stand by apabila ada permintaan berkas rekam medis mendadak serta melakukan koding apabila terdapat operan dari shift sebelumnya.

Berdasarkan hasil perhitungan didapatkan pula bahwa total waktu kerja helper rekam medis cenderung rendah. Hal ini disebabkan oleh tanggungjawab pekerjaan yang dilakukan oleh helper bukan hanya pekerjaan untuk membantu kinerja unit Rekam Medis tetapi seringkali helper ditugaskan untuk membantu pekerjaan di bagian lain yaitu front office sehingga waktu kerja yang dialokasikan helper di unit Rekam Medis terhitung cukup rendah. Waktu kerja helper yang dialokasikan di unit Rekam Medis meliputi kegiatan melakukan distribusi berkas dan juga melakukan filing.

Langkah terakhir sebelum menghitung nilai indeks FTE adalah menghitung waktu kelonggaran. Waktu kerja yang dilakukan karyawan terdiri dari waktu kerja produktif dan waktu kerja non produktif. Waktu kerja produktif merupakan waktu yang digunakan untuk melakukan kegiatan kerja sesuai dengan tugas yang dibebankan sedangkan waktu kerja non produktif adalah waktu kerja yang dialokasikan untuk melakukan kegiatan yang tidak berhubungan langsung dengan tugas yang diberikan. Umumnya waktu kerja non produktif digunakan untuk menghilangkan penat dan beristirahat.

Waktu kelonggaran didapat dari jumlah alokasi waktu yang digunakan untuk melakukan kegiatan di luar pekerjaan (kegiatan non produktif) atau waktu yang digunakan dalam menyelesaikan kegiatan yang tidak terkait dengan kegiatan pokok. Dalam penelitian ini, waktu kelonggaran yang dihitung adalah waktu yang digunakan untuk pergi ke toilet, makan dan juga beribadah. Alokasi waktu kelonggaran tenaga Unit Rekam Medis dalam satu tahun terlihat dalam Tabel 2.

Tabel 2. Hasil Perhitungan Waktu Kelonggaran Tenaga unit Rekam Medis

\begin{tabular}{lcc}
\hline Jabatan & $\begin{array}{c}\text { Total waktu } \\
\text { kelonggaran } \\
\text { (menit/ hari) }\end{array}$ & $\begin{array}{c}\text { Total waktu } \\
\text { kelonggaran } \\
\text { (jam/ tahun) }\end{array}$ \\
\hline Supervisor & 50 & 217 \\
Pelaksana Pagi & 45 & 216 \\
Pelaksana Sore & 50 & 240 \\
Pelaksana Malam & 45 & 216 \\
Helper & 40 & 192 \\
\hline
\end{tabular}

Alokasi waktu yang diperlukan tenaga rekam medis untuk melakukan kegiatan di luar pekerjaan seperti makan, ke toilet dan juga beribadah adalah 40-50 menit per hari. Alokasi waktu tersebut didapatkan dari perhitungan rata-rata lama waktu kelonggaran yang telah tercatat pada daily log. Perhitungan waktu kelonggaran per tahun didapatkan dari waktu kelonggaran per hari dikalikan dengan jumlah hari kerja tersedia tiap kategori tenaga rekam medis yang ada. Kegiatan non produktif ini dilakukan di sela pekerjaan, umumnya saat volume pasien berkurang sehingga aktivitas pelayan dapat terus berjalan. Waktu kelonggaran yang telah diakumulasikan sesuai hari kerja per tahun dapat digunakan dalam perhitungan indeks FTE.

Langkah terakhir dalam melakukan analisis beban kerja dengan metode FTE adalah menghitung nilai indeks FTE beserta melakukan interpretasi berdasarkan hasil yang didapatkan. Indeks FTE dapat ditentukan dengan menghitung total waktu kerja per tahun ditambah dengan waktu kelonggaran per tahun

Tabel 3. Hasil Perhitungan Indeks FTE dan Interpretasi

\begin{tabular}{lcc}
\hline \multicolumn{1}{c}{ Jabatan } & Indeks FTE & $\begin{array}{c}\text { Interpretasi } \\
\text { Hasil }\end{array}$ \\
\hline Supervisor & 1,25 & Normal \\
Pelaksana Shift Pagi & 1,18 & Normal \\
Pelaksana Shift Sore & 0,86 & Underload \\
Pelaksana Shift Malam & 0,37 & Underload \\
Helper & 0,73 & Underload \\
\hline
\end{tabular}


dibagi dengan total jam kerja tersedia dalam satu tahun. Nilai indeks tersebut dapat menunjukkan beban kerja seseorang dengan ketentuan jika nilai indeks $<1$ memiliki beban kerja yang rendah (underload), nilai indeks 1 hingga 1,28 memiliki beban kerja yang normal, dan nilai indeks $>1,28$ memiliki beban kerja yang tinggi (overload).

Berdasarkan hasil perhitungan didapatkan bahwa beban kerja supervisor tergolong normal dengan nilai indeks yang hampir mendekati overload. Supervisor memiliki tugas dan kewajiban yang lebih dibandingkan dengan pelaksana oleh karena itu waktu kerja dan juga beban kerja yang dimiliki lebih besar. Supervisor bertanggung jawab langsung kepada manajer, sehingga apabila manajemen membutuhkan data terkait pasien maka supervisor bertugas untuk menyediakan data tersebut. Penyelenggaraan pelayanan rekam medis didukung oleh kelengkapan laporan mengenai kegiatan rekam medis secara periodik. Kegiatan yang berkaitan dengan kelengkapan laporan ini merupakan tanggungjawab supervisor yang pelaksanaannya membutuhkan waktu yang cukup lama, antara 3-4 jam dengan frekuensi pelaksanaan bulanan dan tahunan. Kegiatan ini pula yang menyebabkan perhitungan beban kerja supervisor memiliki nilai yang lebih tinggi dibandingkan dengan pelaksana rekam medis.

Beban kerja untuk pelaksana rekam medis shift pagi tergolong normal meskipun berdasarkan pencatatan pada daily log dan konfirmasi melalui wawancara terdapat beberapa hari dimana terjadi penambahan kegiatan kerja. Hal tersebut terjadi ketika terdapat kenaikan jumlah pasien yang umumnya terjadi di hari-hari tertentu seperti pada hari senin hingga kamis, adanya berkas rekam medis yang tidak lengkap, permintaan data oleh manajemen ataupun unit terkait dan terkadang masih terdapat operan dari shift sebelumnya yang pekerjaannya dilimpahkan ke pelaksana shift pagi. Namun, kegiatan tersebut tidak terjadi secara periodik sehingga tidak terjadi peningkatan beban kerja yang signifikan. Beban kerja normal merupakan beban kerja dimana karyawan dan pekerjaan yang dilakukan seimbang sehingga tidak mengalami kesulitan dalam melaksanakan pekerjaannya (Ajitia \& Prasetya, 2017).

Pelaksana rekam medis shift sore memiliki beban kerja dalam kategori rendah dikarenakan permintaan untuk pelayanan berkas rekam medis pasien yang lebih sedikit dibandingkan dengan shift pagi. Beban pekerjaan yang terlalu rendah (underload) mengindikasikan bahwa jumlah pekerja yang dipekerjakan terlalu banyak sehingga membuat perusahaan harus mengalokasikan gaji berlebih dengan tingkat produktivitas sama. Ketidakseimbangan beban kerja dalam satu unit kerja dapat menimbulkan kecemburuan antar karyawan sehingga dapat berakibat pada penurunan produktivitas unit (Ajitia \& Prasetya, 2017).

Beban kerja pelaksana rekam medis shift malam termasuk ke dalam kategori rendah. Meskipun memiliki beban kerja yang paling kecil, namun tingkat kelelahan yang terjadi ketika melakukan pekerjaan pada shift malam cukup tinggi dikarenakan memiliki jam kerja yang lebih panjang dari shift lainnya. Hal ini sesuai dengan penelitian yang dilakukan oleh Astuti, et al. (2017) yang menyebutkan bahwa tidak ada hubungan antara beban kerja fisik terhadap kelelahan kerja namun ada hubungan antara shift kerja dengan kelelahan kerja. Petugas rekam medis shift malam bertugas untuk selalu standby dan menahan rasa kantuk apabila terdapat pasien baru dari IGD. Marchelia (2014) yang menyebutkan bahwa manusia mempunyai circadian rhythm yaitu fluktuasi dari berbagai macam fungsi tubuh selama 24 jam. Pada saat malam hari manusia berada dalam fase 'trohotropic' yaitu fase dimana tubuh melakukan pembaharuan cadangan energi atau penguatan kembali sedangkan pada siang hari manusia berada pada fase 'ergotrophic' yaitu fase dimana semua organ dan fungsi tubuh siap untuk melakukan tindakan sehingga tingkat kesalahan, ketelitian dan kecelakaan akan meningkat pada saat malam hari.

Beban kerja helper di unit Rekam Medis termasuk ke dalam kategori rendah dikarenakan helper juga melakukan tugas dari unit lain sedangkan pada saat pengisian daily log hanya dilakukan pencatatan kegiatan kerja yang dilakukan di unit Rekam Medis saja. Peran helper di unit Rekam Medis membantu meringankan beban kerja pelaksana rekam medis, terutama dalam melakukan pendistribusian berkas dan mengembalikan berkas ke dalam rak.

Indeks nilai FTE yang didapatkan, selanjutnya digunakan dalam menentukan jumlah tenaga yang dibutuhkan di unit Rekam Medis Rumah Sakit Bedah Surabaya. Untuk mengetahui jumlah tenaga yang dibutuhkan dapat dilakukan dengan menjumlahkan nilai FTE seluruh tenaga yang ada di satu unit, jika indeks nilai FTE $>1,28$ maka jumlah orang yang dibutuhkan adalah 2 orang. Indeks nilai FTE $>2,56$ membutuhkan 3 orang tenaga kerja, dan seterusnya. Total indeks nilai FTE unit Rekam Medis RS Bedah Surabaya adalah 4,39. Sehingga dapat disimpulkan bahwa jumlah tenaga rekam medis yang dibutuhkan untuk memenuhi pelayanan berkas rekam medis secara optimal adalah 5 orang.

Hasil perhitungan kebutuhan tenaga di Unit Rekam Medis Rumah Sakit Bedah Surabaya menggunakan metode FTE sesuai dengan perhitungan pola kebutuhan tenaga di unit Rekam Medis menggunakan metode WISN yang sebelumnya telah dilakukan oleh pihak unit MSDM Rumah Sakit Bedah yaitu berjumlah 5 orang. Jika alokasi tenaga rekam medis di Rumah Sakit Bedah Surabaya tidak disesuaikan dengan beban kerja yang dilakukan dan tetap terdiri dari 6 orang tenaga termasuk helper, maka akan terjadi kelebihan tenaga dalam unit Rekam Medis. Konsekuensi dari kelebihan tenaga adalah adanya biaya sumber daya manusia yang besar karena setiap tenaga kerja membawa konsekuens biaya yang harus dikeluarkan berupa gaji, lembur bonus, biaya pelatihan dan juga biaya perawatan kesehatan. Oleh karena itu diperlukan adanya suatu pertimbangan yang dilakukan oleh manajemen terkait hal tersebut untuk melakukan optimalisasi kinerja tenaga yang ada (Sari, et al., 2017).

Rohmadi \& Lestari (2013) menyebutkan bahwa dalam upaya mencapai produktivitas yang baik maka perlu mempertimbangkan keseimbangan 
beban kerja dan penempatan tenaga kerja pada pekerjaan yang tepat. Tenaga di unit Rekam Medis saat ini yang berjumlah 5 orang telah cukup untuk memenuhi pelayanan berkas rekam medis pasien rumah sakit. Tenaga kerja yang dibutuhkan saat shift pagi sebanyak 2 orang yang terdiri dari 1 orang supervisor dan 1 orang pelaksana rekam medis. Untuk memenuhi beban kerja pada shift sore cukup menempatkan 1 orang pelaksana rekam medis begitu pula untuk shift malam dapat menempatkan 1 orang pelaksana serta 1 orang pelaksana rekam medis sebagai backup untuk menggantikan apabila terdapat pelaksana lain yang cuti atau libur setelah lepas shift malam. Untuk menghindari adanya beban kerja yang tidak merata dan penumpukan kerja di satu shift saja maka diperlukan adanya koordinasi dan pengaturan operan shift oleh supervisor yang ada di unit Rekam Medis sehingga pekerjaan dapat terselesaikan tepat waktu dan tidak membebani pelaksana di shift berikutnya. Keberadaan helper sendiri memang cukup membantu pelaksanaan kegiatan di unit Rekam Medis tetapi tugas yang selama ini dilakukan oleh helper masih bisa ditangani oleh pelaksana rekam medis lain. Jika keberadaan helper sendiri ditiadakan maka dapat dipastikan tugas unit Rekam Medis tetap akan terselesaikan dengan baik dan beban kerja yang ada di unit Rekam Medis akan lebih merata.

Kedua metode yang digunakan untuk menghitung kebutuhan tenaga di unit Rekam Medis yaitu metode WISN dan FTE menunjukkan hasil yang sama. Hal ini dapat terjadi dikarenakan pada saat proses pengumpulan data uraian pekerjaan dan waktu pelaksanaan pekerjaan dilakukan konfirmasi ulang melalui wawancara pada tenaga yang bersangkutan meskipun saat pengumpulan data uraian pekerjaan menggunakan metode WISN hanya dilakukan pada beberapa tenaga saja, bukan berarti salah satu metode lainnya memiliki kebenaran yang mutlak. Kelemahan dari metode FTE yang dilakukan dengan instrumen berupa daily log seperti yang dilakukan dalam penelitian ini adalah pengisian pada lembar daily log memerlukan adanya kejujuran dari tenaga yang bersangkutan sehingga tidak berdampak pada terjadinya kesalahan dalam melakukan perhitungan beban kerja. Untuk meminimalisir hal tersebut, pengisian daily log akan lebih baik lagi jika didukung oleh suatu sistem informasi yang mempermudah dalam proses pencatatan uraian pekerjaan serta dilakukan komunikasi dan sosialisasi kepada tenaga kerja mengenai tujuan dan manfaat dari pelaksanaan analisis beban kerja untuk perencanaan dan pengembangan SDM dalam organisasi.

\section{SIMPULAN}

Metode FTE merupakan metode yang baik digunakan untuk mengukur beban kerja objektif tenaga medis ataupun non medis karena selain dapat mengukur beban kerja individu juga dapat digunakan untuk menilai kinerja dan produktivitas individu. Berdasarkan perhitungan didapatkan bahwa beban kerja untuk supervisor dan pelaksana rekam medis shift pagi di unit Rekam Medis Rumah Sakit Bedah Surabaya berada dalam kategori normal sedangkan pada pelaksana rekam medis shift sore, shift malam dan helper berada dalam kategori rendah (underload).

Nilai indeks FTE juga dapat digunakan untuk menentukan jumlah tenaga yang dibutuhkan dalam suatu unit kerja. Indeks FTE untuk unit Rekam Medis Rumah Sakit Bedah Surabaya sebesar 4,39 yang menunjukkan bahwa tenaga rekam medis yang dibutuhkan oleh Rumah Sakit Bedah Surabaya sebanyak 5 orang, jumlah ini merupakan jumlah ideal yang dibutuhkan berdasarkan beban kerja yang dilakukan di unit Rekam Medis. Dalam upaya pemerataan beban kerja dapat dilakukan pengawasan operan shift oleh supervisor sehingga tidak terjadi penumpukan pekerjaan di satu shift saja.

Kendala yang terjadi selama pelaksanaan analisis beban kerja menggunakan metode FTE dengan instrumen berupa daily log adalah terdapat beberapa kegiatan yang tidak tercatat pada daily log dan juga membutuhkan kejujuran dari petugas mengenai apa saja kegiatan yang dilakukan dan lama waktu pelaksanaan kegiatan yang dapat memengaruhi hasil perhitungan.

\section{DAFTAR PUSTAKA}

Ajitia, M. \& Prasetya, A. 2017. Efektivitas Manpower Planning dengan Menggunakan Metode Analisis Beban Kerja (Workload Analysis) Berdasarkan Pendekatan Full Time Equivalent. Jurnal Administrasi Bisnis (JAB), Volume 42, pp. 27-35.

Astuti, F.W., Ekawati \& Wahyuni, I. 2017. Hubungan Antara Faktor Individu, Beban Kerja dan Shift Kerja dengan Kelelahan Kerja pada Perawat di RSJD Dr. Amino Gondohutomo Semarang. Jurnal Kesehatan Masyarakat, 5(5), pp. 163-172.

Dannies, N., Halim, V. \& Haryanto, H. 2015. Analisis Beban Kerja PT. X. Jurnal IImiah Mahasiswa Universitas Surabaya, 4(1), pp. 1-12.

Griffith, J.R. \& White, K.R. 2010. Well-Managed Healthcare Organization. 7th ed. Chicago: AUPHA Press.

Hariandja, M.T.E. 2002. Manajemen Sumber Daya Manusia (Pengadaan, Pengembangan, Pengompensasian dan Peningkatan Produktivitas Pegawai). Jakarta: PT Grasindo.

Marcelia, V. 2014. Stres Kerja Ditinjau dari Shift Kerja pada Karyawan. Jurnal IImiah Psikologi Terapan, 2(1), pp. 130-143.

Marlina, L. 2015. Manajemen Sumber Daya Manusia (SDM) dalam Pendidikan. Istinbath, XIV(15), pp. 123-139.

Permatasari, E.D. \& Pudjirahardjo, W.J., 2015. Kelemahan Workload Indicators of Staffing Need sebagai Metode Perhitungan Jumlah Kebutuhan Tenaga Kesehatan di Puskesmas. Jurnal Administrasi Kesehatan Indonesia, 3(1), pp. 89-98.

Rohmadi \& Lestari, A.P. 2013. Prediksi Kebutuhan Tenaga Kerja di Bagian Pendaftaran Pasien Rawat Jalan Berdasarkan Rumus Full Time Equivalent 
(FTE) di RSUD Kota Surakarta Tahun 2014. Jurnal Rekam Medis, VII(1), pp. 1-12.

Sari, W.O.S.R., Sakka, A. \& Paridah. 2017. Analisis Beban Kerja dengan Metode Full Time Equivalent (FTE) pada Dokter Umum di Rumah Sakit Umum Bahteramas Provinsi Sulawesi Tenggara Tahun 2017. Jurnal IImiah Mahasiswa Kesehatan Masyarakat, 2(6), pp. 1-9.

Setiawan, V.B. \& Wulandari, R.D. 2016. Beban Kerja Subyektif dan Obyektif Tenaga Farmasi Rawat Jalan di Rumah Sakit. Jurnal Administrasi Kesehatan Indonesia, 4(1), pp. 28-36.

Sugiono, H.S. \& Palit, H.C., 2016. Penentuan Jumlah Tenaga Kerja pada Departemen MPC: A Case Study. Jurnal Tirta, 4 (2), pp. 223-228.
Supriyatna, Y. 2013. Analisis Kesesuaian Antara Beban Kerja terhadap Jumlah SDM SAP Operasional Divisi Information Technology Shared Services: Studi Kasus PT XYZ, Depok: Universitas Indonesia.

Susilo, R. \& Yustiawan, T. 2015. Perhitungan Tenaga Keperawatan dengan Metode Full Time Equivalent di Rumah Sakit Adi Husada, Undaan Wetan Surabaya. Buletin Penelitian Sistem Kesehatan, 18(4), pp. 399-406.

Tridoyo \& Sriyanto, 2014. Analisis Beban Kerja dengan Metode Full Time Equivalent untuk Mengoptimalkan Kinerja Karyawan pada PT Astra Internasional Tbk-Honda Sales Operation Region Semarang. Industrial Engineering Online Journal e-Journal Undip, 3(2), pp. 1-8. 